Eugene I. Tolpin MD PH D, Jeffrey E. Fletcher PH D, Henry Rosenberg MD Kirsten Michaux Bs

\title{
Effects of anaesthetic agents on erythrocyte fragility: comparison of normal and malignant hyperthermia susceptible patients
}

\begin{abstract}
The effects on erythrocyte fragility of two general anaesthetic agents (halothane and ethanol) and succiny/choline were examined using preparations from 13 normal and four maignant hyperthermia susceptible patients. Erythrocyte fragility was determined by the degree of haemolysis induced in solutions of decreasing asmolarity of $\mathrm{NaCl}$. Halothane caused haemolysis of erythrocytes in an isoosmolar solution, being more porent at $42^{\circ} \mathrm{C}$ than at $32^{\circ} \mathrm{C}$. Haemolysis produced by an hypoosntolar medium or halothane was potentiated by exogenously added phospholipase $A_{2}$. Ethatol did not markedly alter the haemolysis of erythrocytes under conditions of decreasing osmolarity. Succinylchaline $10 \mathrm{mM}$ did not significantly alter the susceptibility of erythrocytes to iysis by halothane. No differences in erythrocyte fragility were observed between preparations from normal and malignant hyperthermia susceptible patients under any of the conditions tested, despite the inclusion of malignant hyperthermia triggering agents in some instances. Although sampling a larger patient population might reveal slight differences between the groups, eryhrocyte fragility lests do not appear to be useful in differentiating malignant hyperthermia susceptible from normal patients.
\end{abstract}

\section{Key words}

HYPERTHERMIA; malignant hyperthermia; BLOOD: erythrocyte fragility; ANAESTHETICS: halothane, ethanol; NEUROMUSCULAR RELAXANTS: succinylcholine; ENZYMES: phospholipase $A_{2}$.

From the Laboratory for the Study of Malignant Hyperthermia, Department of Anesthesiology, Hahnemann University, Philadelphia, PA 19102-1192.

Address correspondence to: Dr. Henry Rosenberg, Professor and Chairman, Department of Anesthesiology, Hahnemann University Hospital, Broad and Vine Streets, Philadelphia, PA 19102-1192.

Supported in part by the Hahnemann Anesthesia Research Foundation and USNIH grant \#GM34872.
Malignant hyperthermia (MH) susceptibility is identified either by a proven personal or family history of $\mathrm{MH}$, or the contracture response of biopsied muscle to halothane or caffeine in vitro. ${ }^{1,2}$ Due to its invasive nature and the equipment and manpower requirements, the in vitro contracture test is not useful for screening the large population that undergoes anaesthesia each year. A test to detect susceptibility to $\mathrm{MH}$ based on the analysis of blood components is, therefore, desirable. Biochemical tests using platelets have been investigated as a means of discriminating MH susceptible from normal individuals, ${ }^{3}$ but have not proven to be satisfactory. ${ }^{4,5}$

Erythrocytes from $\mathrm{MH}$ susceptible pigs are more fragile than those from normal pigs when incubated in hypoosmolar solutions of sodium chloride ${ }^{6-8}$ In contrast to the consistent findings in pigs, investigations on erythrocytes from humans with $\mathrm{MH}$ show increased, decreased, or no change in fragility when compared to control patients. ${ }^{\text {-1] }}$

In the present study we attempted to optimize the conditions for discrimination of $\mathrm{MH}$ susceptible from normal patients based on our current understanding of the mechanisms underlying the disorder (i.e., an enhanced phospholipase $A_{2}$ activity). We used a buffer that would enhance the activity of phospholipase $A_{2}$, which is believed to be the biochenical defect in pigs ${ }^{12}$ and humans ${ }^{13}$ susceptible to $\mathrm{MH}$. Halothane and succinylcholine are the major triggering agents for $\mathrm{MH}$. Therefore, the effects of halothane with and without succinylcholine on erythrocyte fragility were also examined. In addition the effect of ethanol on osmotic fragility was tested, as this weak general anaesthetic agent is known to affect membrane characteristics ${ }^{14}$ and to decrease sarcolemmal calcium uptake. ${ }^{15}$

\section{Methods}

Erythrocyte preparation

Blood $(4.5 \mathrm{ml})$ was collected in tubes containing $0.5 \mathrm{ml}$ 
buffered citrate $(16 \mathrm{mg}$ sodium citrate and $2.1 \mathrm{mg}$ citric acid) and maintained at $4^{\circ} \mathrm{C}$ until used. The donors included 13 normal patients and four with susceptibility to MH as ascertained by in vitro halothane contracture testing using previously reported techniques. ${ }^{16}$ In one case the patient also had previously experienced a fulminant $\mathrm{MH}$ episode. Approval for this study was obtained from the Hahnemann University Human Studies Committee. Patients with chronic anaemia were excluded from the study. After centrifugation of the blood samples at $1000 \times \mathrm{g}$ for eight minutes, the supematant was drawn off and the erythrocyte pellet resuspended in an equal volume of HEPES (N-2-hydroxyethyl piperazine- $\mathrm{N}^{1}-2$. ethane sulfonic acid) buffer $(\mathrm{NaCl} 130 \mathrm{mM}$, HEPES $20 \mathrm{mM}, \mathrm{CaCl}_{2} 2 \mathrm{mM}, \mathrm{pH} 7.40$ ). The centrifugation and resuspension procedure was then repeated twice. The erythrocytes were centrifuged a final time and the supernatant discarded, leaving packed erythrocytes. Citrate was presumed to be removed by these washings. Studies were initiated within three hours of venipuncture.

\section{Osmolarity studies}

Ten stock solutions were prepared containing $\mathrm{CaCl}_{2}$ $2 \mathrm{mM}$, HEPES $20 \mathrm{mM}$ at $\mathrm{pH} 7.40$, and $\mathrm{NaCl}$ at 13,26 , $32.5,39,45.5,52,58.5,71.5,84.5$, or $130 \mathrm{mM}$ concentration. Each solution was designated as a fraction of the concentration of the $\mathrm{NaCl}$ divided by 130; specifically those mentioned correspond to $0.1,0.2,0.25,0.30$, $0.35,0.40,0.45,0.55,0.65$, and 1.0 fractional concentration of $\mathrm{NaCl} 130 \mathrm{mM}$. For osmotic fragility studies, $5 \mathrm{ml}$ of stock solution was delivered into each tube $(16 \times 100 \mathrm{~mm})$. For studies involving ethanol, a solume of 95 per cent ethanol equal to 1,5 , or 10 per cent of $5 \mathrm{ml}$ was added to each tube. When phospholipase $A_{2}$ was used, it was added in a volume of $50 \mu$. The tubes containing ethanol or phospholipase $\mathrm{A}_{2}$ were thoroughly mixed. Fifty $\mu \mathrm{l}$ of packed erythrocytes was added to each tubc. The tubes were again thoroughly mixed and the samples incubated at $32^{\circ} \mathrm{C}$ or $42^{\circ} \mathrm{C}$ for one hour in uncapped test tubes. The ethanol experiments were done in capped tubes.

After incubation, samples were centrifuged at $1000 \times \mathrm{g}$ for $8 \mathrm{~min}$. The absorbance of the supernatant was read at $540 \mathrm{~nm}$ against a distilled water blank on a Shimadzu UV-120-01 spectrophotometer. The absorbance of any sample was compared to the value representing 100 per cent haemolysis $(50 \mu \mathrm{l}$ of erythrocytes in $5 \mathrm{ml}$ distilled water or 100 per cent halothane saturated solution, respectively) to yield per cent haemolysis.

\section{Halothane studies}

Into a glass bottle was added $500 \mathrm{ml}$ of buffer containing $\mathrm{NaCl} 130 \mathrm{mM}, \mathrm{CaCl}_{2} 2 \mathrm{mM}$, HEPES $20 \mathrm{mM}$ at $\mathrm{pH} 7.40$, along with $25 \mathrm{ml}$ of liquid halothane and a magnetic stirbar. The glass stoppered bottle was stored at $32^{\circ} \mathrm{C}$ with continuous stirring for several hours. The aqueous phase of this two phase (buffer/halothane) solution was designated the halothane saturated solution.

The halothane and buffer solution was left at room temperature for $5 \mathrm{~min}$ before use. To test tubes ( $16 \times$ $100 \mathrm{~mm}$; size is critical) containing $50 \mu \mathrm{l}$ of erythrocytes in precalculated volumes of $\mathrm{NaCl} 130 \mathrm{mM}$, HEPES $20 \mathrm{mM}, \mathrm{CaCl}_{2} 2.0 \mathrm{mM}$ buffered solution were added the appropriate volume of the halothane saturated solution to produce a final volume of $5 \mathrm{ml}$ and final concentrations of $100,90,80,70,60,50,40,30$, and 20 per cent halothane saturated solutions. For example, a final 60 per cent halothane saturated solution would consist of $2 \mathrm{ml} \mathrm{NaCl} /$ $\mathrm{HEPES} / \mathrm{CaCl}_{2}$ buffer and $3 \mathrm{ml}$ of halothane saturated solution. The tubes were immediately capped with rubber stoppers and thoroughly mixed. If succinylcholine was included, it was added to the erythrocyte-buffer suspension at a final concentration of $0.01 \mathrm{M}$. Likewise, if phospholipase $A_{2}$ from bee venom (Sigma Chemical Co. St. Louis, MO) was used it was added to a final concentration of $1 \mu \mathrm{M}$. The tubes were then incubated at $32^{\circ} \mathrm{C}$ or $42^{\circ} \mathrm{C}$ for one hour and the absorbance determined as described above.

\section{Results}

We first tested the hypothesis that elevated phospholipase $A_{2}$ activity can potentiate the effects of halothane on erythrocytes in the same manner as observed in skeletal muscle. ${ }^{13}$ Bce venom phospholipase $A_{2} \mid \mu \mathrm{M}$ in $\mathrm{NaCl}$ $130 \mathrm{mM}$, HEPES $20 \mathrm{mM}, \mathrm{CaCl}_{2} 2 \mathrm{mM}$ at pH 7.4, did not induce haemolysis of red blood cells (Figure 1). A 40 per cent halothane saturated solution also did not induce more than five per cent haemolysis under the same conditions (Figure 1). The combination of a 40 per cent halothane saturated solution and phospholipase $A_{2} 1 \mu \mathrm{M}$ resulted in levels of haemolysis, which were significantly greater $(p<0.001$; two-tailed grouped Student's t test) than in the absence of phospholipase $A_{2}$ (Figure 1). Thus, phospholipase $A_{2}$ activity does potentiate the action of halothane on red blood cells in a manner similar to that observed in skeletal muscle. Therefore, all subsequent studies were done in $\mathrm{Ca}^{2+}$-containing buffer to elevate the activity of any calcium-dependent endogenous phospholipase $\mathrm{A}_{2}$ that may be present in human erythrocytes. Phospholipase $A_{2}$ addition also enhanced the fragility of red blood cells as determined by osmotic lysis. Incubation of erythrocytes in an 0.50 fraction of initial $\mathrm{NaCl}$ solution resulted in very little haemolysis; whereas, incubation of the cells in the same medium containing phospholipase $A_{2} 1 \mu \mathrm{M}$ resulted in significantly greater $(p<0.001 ;$ two-tailed grouped Student's t test) hacmolysis than in the absence of phospholipase $A_{2}$ (Figure 1).

The per cent haemolysis as a function of changing 


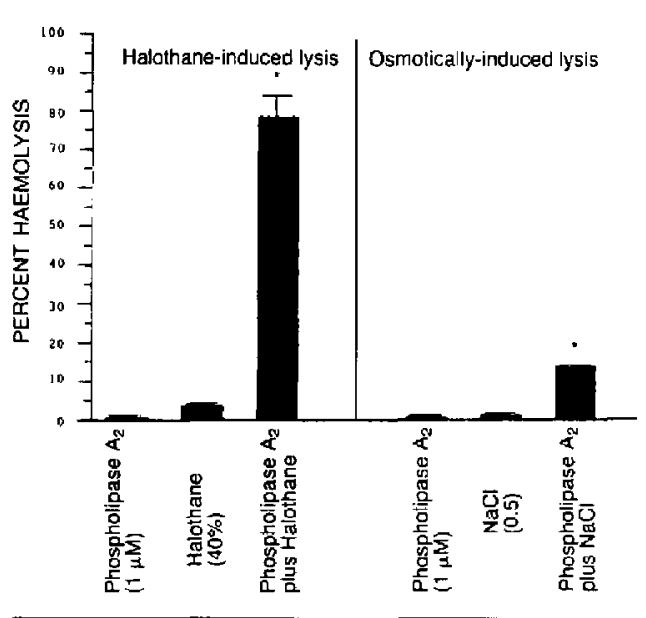

FIGURE 1 Effects of phospholipase $A_{2}$ on halothane- and osmotically-jnduced lysis of red blood cells. In the left panel a solution of halothane equivalent to 40 per eent of the saturaled halothane solution was incubated in the presence or absence of phaspholipase $A_{2} 1 \mu M$. In the right panel a solution containing 50 per cent fraction of the $\mathrm{NaCl}$ concentration was incubated in the presence or absence of phospholipase $A_{2} \mid \mu M$. Shown are the mean \pm SD for three determinations. The asterisk denotes significantly $(p<0.001)$ greater haemolysis than in the absence of phospholipase $A_{2}$.

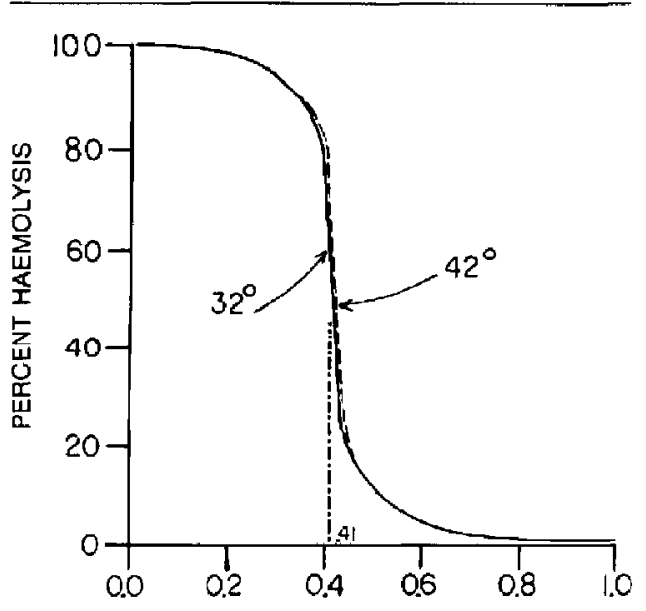

FRACTION INITIAL NACI CONCENTRATION

FIGURE 2 Representative $\mathrm{NaCl}$ osmolarity dependent haemolysis curves of erythrocytes incubated at $32^{\circ} \mathrm{C}$ and $42^{\circ} \mathrm{C}$ for a single non-MH susceptible patient. The $\mathrm{NaCl}$ fraction is expressed as a fraction of $\mathrm{NaCl} 130 \mathrm{mM}$. The 50 per cent haemolysis points for both temperatures are equivalent to $\mathrm{NaCl} 53 \mathrm{mM}$.

\section{OSMOLAR DEPENDENT FRAGILITY}

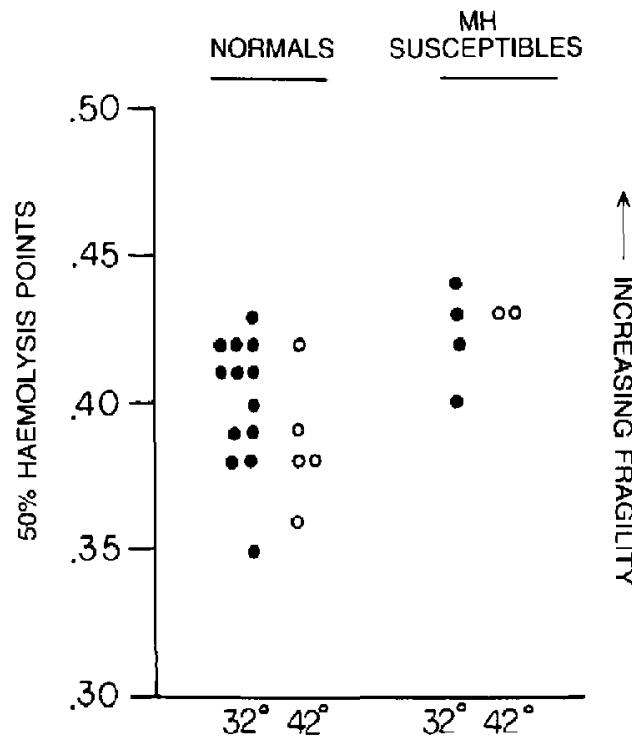

FIGURE 3 Scatter plots of 50 per cent haemolysis points based on varying osmolarity of $\mathrm{NaCl}$ solutions for normal and $\mathrm{MH}$ susceptible patients. Each solution contains HEPES $20 \mathrm{mM}, \mathrm{CaCl}_{2} 2 \mathrm{mM}$, and $\mathrm{NaCl}$ at various concentrations.

osmolarity is shown in Figure 2 for one patient not susceptible to MH. Samples from each patient were run in duplicate and were usually within one per cent of each other. The 50 per cent haemolysis point is equivalent to a solution containing $\mathrm{NaCl} 53 \mathrm{mM}$, HEPES $20 \mathrm{mM}$, and $\mathrm{CaCl}_{2} 2 \mathrm{mM}$.

Lysis of red blood cells from MH susceptible patients was then compared to those from normal patients in an hypoosmolar solution. The 50 per cent haemolysis points based on varying osmolarity are shown in Figure 3. Although tending toward the expected decreased fragility at higher temperatures, ${ }^{17}$ there was no statistically significant difference $(p>0.05)$ between 50 per cent haemolysis points for normal patients at $32^{\circ} \mathrm{C}(0.401 \pm 0.006$; mean $\pm S E M)$ or $42^{\circ} \mathrm{C}(0.386 \pm 0.010)$ as determined by the two-tailed grouped Student's t test. The values of 50 per cent haemolysis for normal patients at $32^{\circ} \mathrm{C}$ wcre not statistically different ( $p>0.05$; wo-tailed grouped Student's $t$ test) and, more importantly, overlap considerably with those from MH susceptible patients $(0.423 \pm 0.008)$.

Figure 4 demonstrates representative haemolysis curves for one patient not susceptible to $\mathrm{MH}$ as a function of per cent halothane saturation. Fifty per cent haemolysis 


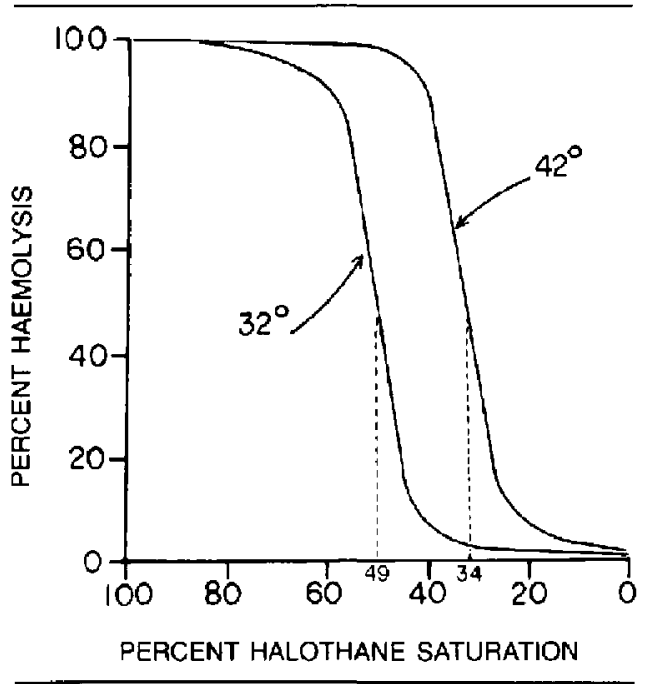

FIGURE 4 Representative hacmolys is curves for erythrocytes incubated at $32^{\circ} \mathrm{C}$ and $42^{\circ} \mathrm{C}$ as a function of per cent halothane saturation for a single non- $\mathrm{MH}$ susceptible patient. The suspension medium contains $\mathrm{NaCl} 130 \mathrm{mM}$, HEPES $20 \mathrm{mM}$ and $\mathrm{CaCl}_{2} 2 \mathrm{mM}$ a $\mathrm{pH} 7.4$. Fifty per cent haemolysis points occur at 49 and 34 per cent saturation for preparations incubated at $32^{\circ} \mathrm{C}$ and $42^{\circ} \mathrm{C}$, respectively.

points at $32^{\circ} \mathrm{C}$ and $42^{\circ} \mathrm{C}$ are 49 and 34 per cent halothane saturation, respectively, suggesting an increase in susceptibility to halothane lysis at $42^{\circ} \mathrm{C}$. Curves identical to those for nonsusceptible patients were observed with erythrocytes from $\mathrm{MH}$ susceptible patients.

The effect of succinylcholine on halothane-induced lysis was compared for normal and $\mathrm{MH}$ susceptible patients. Figure 5 shows results based on halothane enhanced fragility. A one-way ANOVA (completely randomized design) and Duncan's multiple-range test (at

TABLE Fraction of $\mathrm{NaCl}$ concentration to produce $50 \%$ baemolysis

\begin{tabular}{lllll}
\hline \multicolumn{5}{c}{ Volume per cent ethanol soiution } \\
\cline { 2 - 5 } & $0 \%$ & $1 \%$ & $5 \%$ & $10 \%$ \\
\hline MH negative & $0.35-0.43$ & $0.41-0.43$ & $0.41-0.44$ & $0.44-0.48$ \\
& $(13)$ & $(3)$ & $(3)$ & $(3)$ \\
MH positive & $0.40-0.44$ & $0.40-0.43$ & $0.42-0.43$ & $0.42-0.47$ \\
& $(4)$ & $(2)$ & $(2)$ & $(2)$
\end{tabular}

The range of $50 \%$ haemolysis points for preparations from MH negative and $\mathrm{MH}$ positive patients at various concentrations of ethanol in solutions containing $\mathrm{NaCl} 13-130 \mathrm{mM}$, HEPES $20 \mathrm{mM}, \mathrm{CaCl}_{2} 2 \mathrm{mM}$ at $37^{\circ} \mathrm{C}$ and $\mathrm{pH} 7.4$. Values are expressed as the fractional concentralion of NaCl causing 50\% hemolysis (see Methods). Numbers in paren theses represent the number of patients studied.

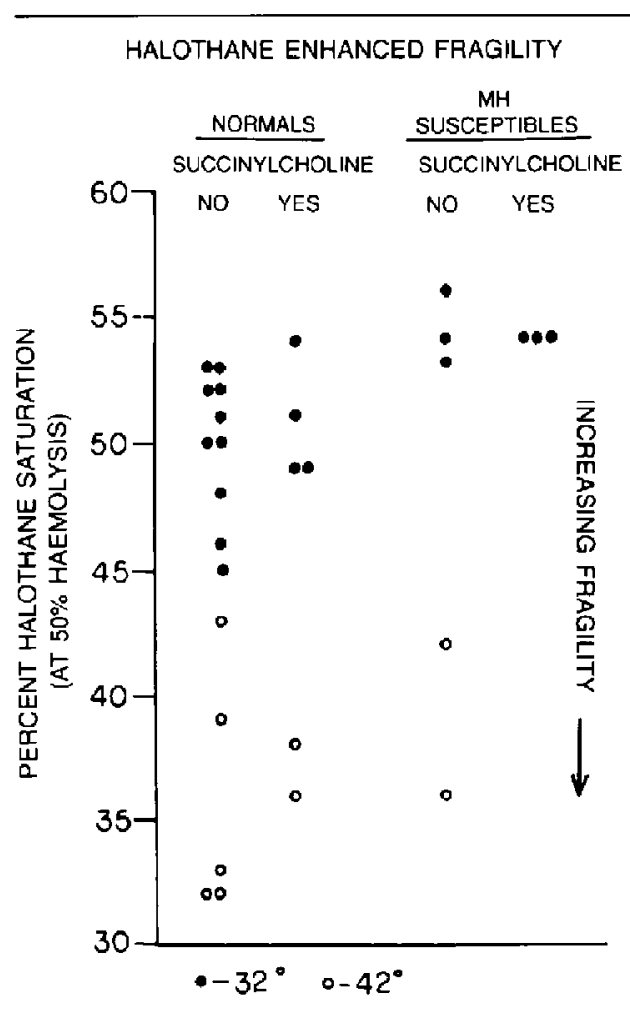

FIGURE 5 Scatter plots of 50 per cent haemolysis points based an varying halothane solutions. The suspension medium contained $\mathrm{NaCl}$ $130 \mathrm{mM}$, HEPES $20 \mathrm{mM}$ and $\mathrm{CaCl}_{2} 2 \mathrm{mM}$ at $\mathrm{pH} 7.4$, with or without succinyleholine $0.01 \mathrm{M}$.

a level of $p<0.05$ ) were used to analyze the data in Figure 5 , excluding conditions in which there were only two data points. Again the values of the 50 per cent haemolysis points between normal $(50.0 \pm 0.9)$ and $\mathrm{MH}$ susceptible $(54.3 \pm 0.9)$ patients were not significantly different and overlap at $32^{\circ} \mathrm{C}$. For both the normal and MH susceptible patients, addition of succinylcholine did not change the values of 50 per cent haemolysis at $32^{\circ} \mathrm{C}$. The only statistically significant finding $(\mathrm{p}<0.05)$ was the increased fragility to halothane at $42^{\circ} \mathrm{C}(35.8 \pm 2.2) \mathrm{com}-$ pared to $32^{\circ} \mathrm{C}(50.0 \pm 0.09)$ for erythrocytes from normal patients.

The effects of ethanol on hypoosmolar lysis were tested at three concentrations of ethanol. The ranges for 50 per cent haemolysis of solutions containing ethanol at varying osmolar concentrations are shown in the Table. Preparations from nonsusceptible patients were slightly more fragile in the presence of ethanol ten per cent when 
compared to the absence of ethanol ( $p<0.05$; two-tailed grouped Student's $t$ test). No differences were found between the response of erythrocytes from normal and MH susceptible patients.

In order to determine if the halothane concentrations were influenced by the number of erythrocytes in a sample, the halothane haemolysis studies without succinylcholine were repeated for preparations from four patients using volumes of erythrocytes from 25 to $150 \mu \mathrm{l}$. No change in the haemolysis curves were noted (results not shown).

\section{Discussion}

The standard method of determining osmotic fragility involves serial dilutions of a sodium chloride solution in a phosphate buffer. ${ }^{17,18}$ The goal of the present study was to alter the normal incubation conditions in such a manner as to increase the probability of distinguishing $\mathrm{MH}$ susceptible from normal patients. Our choice of incubation buffer was based on the current understanding of mechanisms underlying $\mathrm{MH}$.

Elevated phospholipase $A_{2}$ activity is believed to be the defect in porcine ${ }^{12}$ and human ${ }^{13} \mathrm{MH}$. In the present study we found that enhanced phospholipase $\mathrm{A}_{2}$ activity can potentiate halothane-induced haemolysis of erythrocytes similar to the synergism observed with these agents in skeletal muscle. ${ }^{13}$ In addition, increased phospholipase $\mathrm{A}_{2}$ activity results in red blood cells with greater fragility when tested for hypoosmolar lysis. Since in most tissues phospholipase $A_{2}$ activity appears in virtually all cell fractions. ${ }^{19}$ it should be present in all membranes, including the plasma membrane of red blood cells. The presence of phospholipase $A_{2}$ in the red blood cell of pigs could explain the ability to distinguish $\mathrm{MH}$ susceptible from nonsusceptible pigs. While phospholipase $A_{2}$ activity is abundant in red blood cells from some species, it is not present to a great extent in red blood cells from all species ${ }^{19}$ Human red blood cells do not contain detectable levels of a major product of phospholipase $A_{2}$ activity, free arachidonic acid, suggesting these cells do not have much, if any, phospholipase $A_{2}$ (unpublished observations). In contrast porcine red blood cells have detectable amounts of arachidonic acid (about $4 \mathrm{pmol}^{\text {. }}$ $\mathrm{mg}^{-1}$ protein; unpublished observations). We added $\mathrm{Ca}^{2+}$ to the incubation buffer, to optimize phospholipase $A_{z}$ activity, ${ }^{19}$ and possibly allow discrimination of $\mathrm{MH}$ susceptible and nonsusceptible patients using the red blood cell fragility test. Since calcium ions at a concentration of $2 \mathrm{mM}$ precipitate with the phosphate buffer normally used in studies of erythrocyte fragility, we chose a HEPES buffer for our studies. Since halothane is known to precipitate episodes of $\mathrm{MH}$, we also tested its ability to discriminate $\mathrm{MH}$ susceptible from nonsusceptible patients using the red blood cell model.

The 50 per cent haemolysis points of erythrocytes from the normal patients in the present study range from 0.35 to 0.43 fraction of the $\mathrm{NaCl}$ solution. This is equivalent to 127-148 milliosmolarity ( $\mathrm{mOsmol} \cdot \mathrm{L}^{-1}$ ). To convert from the fraction of $\mathrm{NaCl}$ used in our study to $\mathrm{mOsmol} \cdot \mathrm{L}^{-1}$, it is necessary to multiply the fraction of $\mathrm{NaCl}$ by 260 (mOsmol $\cdot \mathrm{L}^{-1}$ of $\mathrm{NaCl}$ ) and add $36\left(\mathrm{mOsmol} \cdot \mathrm{L}^{-1}\right.$ of HEPES $20 \mathrm{mM}=30$ at $\mathrm{pH} 7.4$ and the $\mathrm{mOsmol} \cdot \mathrm{L}^{-1}$ of $\mathrm{CaCl}_{2} 2 \mathrm{mM}=6$ ). Normal patient5 exhibit a range of 50 per cent haemolysis points of $0.400-0.445$ per cent $\mathrm{NaCl}$ at $20^{\circ} \mathrm{C}$. ${ }^{18}$ These haemolysis points convert to $0.372-$ 0.417 per cent $\mathrm{NaCl}$ at $32^{\circ} \mathrm{C}$ using the standard temperature correction factor, ${ }^{17}$ or $127-143 \mathrm{mOsmol} \cdot \mathrm{L}^{-1}$ (342 mOsmol $\cdot \mathrm{L}^{-1} \times$ fraction of $\mathrm{NaCl}$ ). Therefore, our modified buffer yields results comparable to buffers traditionally used in studies of red blood cell fragility. In the present study, the range of 50 per cent haemolysis points for $\mathrm{MH}$ patients was similar to that of normal patients.

Although lysis of erythrocytes by a saturated halothane solution has been reported, ${ }^{20}$ the present study is the firs: description of dose related haemolysis induced by halothane. This study provides a valuable model for studying the action halothane on membranes, as suggested by the results with phospholipase $A_{2}$ and halothane. The relative independence of the value of 50 per cent hacmolysis from erythrocyte concentration indicates that haemolysis depends more upon halothane tension than on total halothane concentration. Incubation of erythrocytes in halothane containing solutions at $42^{\circ} \mathrm{C}$ did markedly increase the fragility of ery throcytes relative to incubation at $32^{\circ} \mathrm{C}$. The saturated vapour pressure increases with increasing temperature, whereas the solubility of halothane should decrease. Therefore, the same mass of halothane should have a greater tension at $42^{\circ} \mathrm{C}$ than at $32^{\circ} \mathrm{C}$, further supporting halothane tension rather than total content as the major factor in haemolysis. The temperature-dependent increase in halothane-induced fragility appeared to be the same in $\mathrm{MH}$ susceptible and nonsusceptible patients.

In contrast to the marked lytic effects of halothane on erythrocytes, ethanol had only a slight effect on increasing red blood cell fragility. Ethanol did not increase the sensitivity of the osmotic fragility test for distinguishing MH susceptible patients from normal patients. Succinylcholine had no effect on lysis caused by halothane. The effects of ethanol and succinylcholine were similar for preparations from normal or $\mathrm{MH}$ susceptible patients

Although a larger sample size might reveal slight differences between erythrocytes from normal and $\mathrm{MH}$ susceptible patients, it is unlikely that fragility tests will 
show the sensitivity seen using in vitro contracture tests. Addition of calcium, succinylcholine, or halothane did not improve the ability to discriminate $\mathrm{MH}$ susceptible from normal patients using erythrocyte fragility tests. If elevated phospholipase $A_{2}$ activity in skeletal muscle is the cause of $\mathrm{MH}$, as suggested by some investigators, ${ }^{12,13}$ then cither human red blood cells have too little phospholipase $A_{2}$ activity ${ }^{19}$ for detection of $\mathrm{MH}$ susceptible patients using erythrocyte fragility tests, or the enzyme in red blood cells differs from that in skeletal muscle.

In summary, the use of erythrocyte fragility tests based on changing osmolarity with or without ethanol and based on changing halothane tensions with or without succinylcholine do not provide enough sensitivity to discriminate MH susceptible patients from the normal population. These results do not exclude the possibility that slight differences in red blood cell membrane structure or function may exist between normal and MH susceptible patients and that such differences may be detected by either a larger sample size or by other assays.

\section{References}

1 Gronert GA. Malignant hyperthermia. Anesthesiology 1980; 53: 395-423.

2 Rosenberg $H$, Reed $S$. In vitro contracture tests for susceptibility to malignant hyperthermia. Anesth Analg 1983; 62: 415-20

3 Solomons CC, Masson NC. Platelet model for halothaneinduced effects of nucleotide metabolism applied to malignant hypertherrnia. Acta Anesthesiol Scand $1984 ; 28$ : $185-90$

4 Giger U, Kaplan RF. Halothane-induced ATP depletion in platelets from patients susceptible to malignant hyperthermia and from controls. Anesthesiology 1983; 59 : 347-52.

5 Lee $M B$, Adragna MG, Edwards $L$. The use of platelet nucleotide assay as a possible diagnostic test for malignant hyperthermia. Anesthesiology 1985; 63: 311-5.

6 Cheah KS, Cheah AM. Mitochondrial calcium, erythrocyte fragility, and porcine malignant hypetthermia. FEBS Letter 1979; 107: 265-8.

7 Harrison GG, Verburg C. Erythrocyte osmotic fragility in hyperthermia-susceptible swine. Br J Anaesth 1973; 45: $131-3$.

8 King WA, Olivier L, Basrur PK. Erythrocyte osmotic response test on malignant hyperthermia-susceptible pigs, Ann Genet Sel Anim 1976; 8: 537-40.

9 Kelstrup J, Haase J, Jorni J Reske-Nielson E, Hanel HK. Malignant hyperthermia in a family. Acta Anesthesiol Scand 1973; 17: 283-4,

10 Zsigmond EK, Penner J. Kothary SP. Normal erythrocyte fragility and abnormal platelet aggregation in $\mathrm{MH}$ tamilies: a pilot study. In: Second International Symposium on Malignant Hyperthermia (Aldrete JA, Britt BA, Eds.) 213-9, New York: Grune and Stratton, 1978.

11 Godin DV, Herring FG, MacLeod PJM. Malignant hyperthenuia: characterization of erythrocyte menibranes from individuals at risk. J Med 1981; 12: 35-49.

12 Cheah $K S$, Cheah AM. Skeletal muscle mitochondrial phospholipase $A_{2}$ and the interaction of mitochondria and sarcoplasmic reticulum in porcine malignant hyperthermia Biochim Biophys Acta 1981; 638: 40-9.

13 Fletcher JE, Rosenberg $H$. In vitro muscle contractures induced by halothane and suxamethoniurn: II. Human skeletal muscle from normal and malignant hyperthermia susceptible patients. Br J Anaesth 1986; 58: 1433-9.

14 Seeman P. Kuant WO, Sauks T. Argent W. Membrane expansion of intact erythrocytes by anaesthetics. Biochim Biophys Acta 1969; 183: 490-8.

15 Sivartz $M H$, Repke DI, Katz AM, Rubin E. Effects of ethanol on calcium binding and calcium uptake by cardiac microsomes. Biochern Pharmacol 1974; 23: 2369-76.

16 Fietcher JE. Rosenberg $H$. In virro interaction between halcthane and succinylcholine in human skeleta! muscle: Implications for malignant hyperthermia and masseter muscle rigidity. Anesthesiology 1985; 63: 190-4.

17 Parpart AK, Lorenz PB, Parpart ER, Gregg JK, Chase $A M$. The osmotic resistance (fragility) of human red cells. I Clin Invest 1947; 26: 636-40.

18 Dacie JV, Lewis SM. Practical Hacmatology. New York, Grune \& Stratton: 1968.

19 Waite $M$. Approaches to the study of mammalian cellular phospholipases. J Lipid Res 1985; 26: 1379-88.

20 Lin PS, Wallach DFH, Mikeisen RB, Schmnidtullich R. Action of halothane on human erythrocytes. Mechanisms of cell lysis and production of sealed ghosts. Biochim Biophys Acta 1975; 401: 73-82. 


\section{Résumé}

Les effets de la jragilité érythrocytaire produite par deux agents anesthésiques généraus (I'halothane et l'êthanol) et par la succinylcholine ont été examinés à l'aide de préparations provenant de treize patiens normaux ef de quatre patients susceptibles d l'hyperthermie maligne. La fragilité êrythrocy. saire a ûté déterminée par lo degré d'hémolyse induit par des solutions d"osmolarité décroissante de $\mathrm{NaCl}$. L'halothane a causé une hémalyse des érythrocytes dans une solution isoosmolaire, qui êtait plus puissante à $42^{\circ} \mathrm{C}$ qu'à $32^{\circ} \mathrm{C}$. L' hémolyse produite par un milieu hypoosmolaire ou par l'halothane a été potentialisée par l'ajout exogène de phospholipase $A_{2}$. L'éthanol n'a pas modifié de façon marquée l'hémolyse des érythrocyres dans des conditions d'osmolarité décroissante. La susceptibilitê de lyse des ergthrocytes causée par l'halothane n'a pas été modifíe de façon significative par les $10 \mathrm{mM}$ de succinylcholine. On a remarqué aucune différence darts la fragilité érythrocytaire entre les préparations provenant des patients normaux es celles provenant de patients susceptibles a I"hyperthermie maligne, dons aucune des epreuves verifiées, malgré l'inclusion d'agents déclencheurs d'hyperthermic maligne dans certains cas. Quoique l'échantillonnage d'une population plus grande de patients pourrait révéler des différences légères entre les groupes, les tests de fragilitê érythrocytaire ne semblent pas être utiles pour différencier les patients normaux des potients suscepsibles à l"hyperthermie maligne. 